\title{
PENGARUH PEMBERIAN SARI KULIT NANAS (Ananas comosus (L) Merr) TERHADAP JUMLAH KOLONI BAKTERI PADA IKAN BANDENG (Chanos chanos $\mathrm{F}$.)
}

\author{
Zainal Berlian ${ }^{1}$, Fitratul Aini ${ }^{2}$, Melda Yunita ${ }^{3 *}$ \\ 1,2,3 Prodi Pendidikan Biologi, Fakultas Tarbiyah Dan Keguruan, \\ UIN Raden Fatah Palembang, \\ Jl. Prof, K. H. Zainal Abidin Fikri No. IA KM 3,5, Palembang \\ e-mail : meldayunita0510@gmail.com \\ Diterima 2 Juli 2016, Disetujui 11 Oktober 2016
}

\begin{abstract}
Pineapple rind (Anana chomosus (L) Merr) is household waste has not been used optimally. Rind the pineapple contains bromelain enzymes, citric acid and phenols, to inhibit bacterial growth. The research objective test ativitas antibacterial (Ananas chomosus $(L)$ Merr) to fish. The study design used a completely randomized design (CRD), the treatment of PO (0\%), P1 (12.5\%), P2 (25\%), P3 $(50 \%)$ and $P 4(100 \%)$. Results of analysis of variance (ANOVA), the concentration extract pineapple rind (Anana chomosus $(L)$ Merr) gives significant differences $(p>0.01)$ to the number of bacterial colonies, where Fh > Ft. The results showed pineapple rind (Anana chomosus (L) Merr) has antibacterial activity
\end{abstract}

Keywords: Chanos chanos, pineapple rind (Anana chomosus (L) Merr)

\section{PENDAHULUAN}

Indonesia sebagai negara maritim, mempunyai potensi yang besar dalam perikanan, baik perikanan air tawar, air payau, maupun air laut. Salah satu produk perikanan yang sering dikonsumsi oleh masyarakat adalah ikan bandeng. Ikan bandeng merupakan suatu komoditas perikanan yang memiliki rasa cukup enak dan gurih, sehingga banyak digemari masyarakat. Ikan bandeng digolongkan sebagai ikan berprotein tinggi dan berkadar lemak rendah. Ikan bandeng (Chanos chanos Forsk.) adalah jenis ikan air payau yang mempunyai prospek cukup baik untuk dikembangkan karena banyak digemari masyarakat (Purnomowati, 2007).

Produksi bandeng secara nasional saat ini menempati urutan ke-enam setelah rumput laut, patin, nila, lele, dan udang. Catatan Kementerian Kelautan Perikanan (KKP) menunjukkan produksi budidaya ikan bandeng meningkat lebih dari $17 \%$ tiap tahunnya. Kasubdit Budidaya Air
Payau Laut menyampaikan keterangan bahwa, produksi bandeng 2012 tercatat 503.400 ton dan di 2013 ditarget mencapai 604.000 ton, kemudian diperkirakan pada 2014 akan menembus 700.000 ton (MAI, 2014). Komoditi perikanan seperti ikan bandeng juga memiliki sifat mudah rusak dan busuk. Ikan bandeng segar memiliki daya simpan hingga 5-8 jam setelah penangkapan. Daya tahan ikan yang sangat singkat ini dipengaruhi juga oleh kadar air pada ikan yang sangat tinggi, yaitu mencapai $80 \%$ berat ikan. Faktor lain yang berperan dalam pembusukan yaitu perubahan yang bersifat enzimatis, mikrobiologis maupun fisis yaitu pada saat pengangkutan dan penyimpanan (Buckle et al, 1987).

Badan Standardisasi Nasional telah mengeluarkan SNI 7388 tahun 2009 mengenai kualitas mutu pangan berdasarkan cemaran fisik, cemaran kimia dan cemaran mikroba dalam pangan, khusus ikan dan produk perikanan segar 
termasuk ikan bandeng segar. Penjual ikan banyak yang menggunakan penyimpanan dengan es batu, selain itu masyarakat di rumah juga biasa menyimpan ikan pada suhu kulkas biasa bukan di freezer. Suhu yang biasa digunakan untuk penyimpanan bahan pangan pada pendinginan adalah 5$10^{\circ} \mathrm{C}$ (Buckle et al, 1987). Penyimpanan suhu $15-20^{\circ} \mathrm{C}$ ikan dapat bertahan hingga 2 hari, sedangkan pada suhu $5^{\circ} \mathrm{C}$ tahan selama 5-6 hari tergantung spesies ikan (Mahatmanti et al, 2010). Kecurangan paling berbahaya dalam proses pengawetan ikan adalah dengan menambahkan bahan pengawet kimia seperti formalin. Berdasarkan hasil pemantauan dan pengujian yang dilakukan oleh Dinas Peternakan dan Perikanan, kebanyakan ikan yang dijual mengandung formalin diantaranya ikan bandeng, lajang, kembung, udang, lajang kering, teri kering, cakalang, serta nila (Fajar, 2013). Alternatif alami yang efektif dan efisien diperlukan sebagai bahan pengawet yang mampu memperpanjang daya simpan makanan tanpa mengubah sifat-sifat pada ikan bandeng. Salah satu yang memiliki potensi untuk pengawetan makanan untuk menghambatan aktivitas mikroba adalah buah nanas.

Nanas (Ananas comosus (L.)Merr.) banyak mengandung senyawa asam sitrat yang menyebabkan rasa asam pada nanas. Asam sitrat memiliki kemampuan merusak membran bakteri dan memisahkannya dengan sel. Sel akan mempertahankan $\mathrm{pH}$ dalam sel yang membutuhkan banyak energi. Buah nanas memiliki kandungan khusus berupa senyawa bromelin yang memiliki fungsi memecah protein membran sel bakteri (Caesarita, 2011). Senyawa fenol memiliki kemampuan mendenaturasi protein sel bakteri (Rakhmanda, 2008). Kandungan asam sitrat, fenol dan senyawa bromelin pada nanas diduga dapat menghambat proses pembusukan ikan oleh mikroorganisme.

Mikroorganisme yang hidup pada makanan mampu menghasilkan spora dalam usus dan menimbulkan penyakit. Seperti halnya ikan yang mudah tercemar oleh berbagai mikroorganisme dari lingkungannya. Beberapa jenis mikroorganisme yang sering mencemari ikan tersebut adalah Escheria coli dan Salmonella sp serta mikroba patogen lainnya. Pencemaran mikroba pada ikan merupakan hasil kontaminasi langsung dan tidak langsung dengan sumber pencemaran, seperti tanah, udara, air, debu, saluran pernafasan dan saluran pencernaan manusia maupun hewan (Puspita, 2012).

Berdasarkan kejadian-kejadian tersebut, perlu dicari alternatif yang dapat menekan pertumbuhan bakteri pada ikan tanpa menggunakan bahan berbahaya seperti pengawet berupa formalin atau bahan kimia lainnya yang dapat membahayakan kesehatan. Tujuan penelitian menguji ativitas antibakteri (Ananas chomosus (L) Merr) terhadap ikan bandeng.

\section{METODE}

\section{Waktu dan Tempat}

Penelitian ini dilaksanakan di Laboratorium Biologi Universitas Islam Negeri (UIN) Raden Fatah Palembang, dengan pelaksanaan pada bulan Oktober 2015.

\section{Alat dan Bahan}

Alat yang digunakan dalam penelitian ini adalah pisau, wadah ikan, cawan petri, blender, saringan, kertas saring, termometer, $\mathrm{pH}$ meter, oven, lemari pendingin, bekerglass, hot plate, erlenmeyer, kapas, aluminium foil, ose, tabung steril, incubator, mikroskop, mikropipet, bunsen, korek api, spidol permanen, dan colony counter.Bahan yang digunakan yaitu daging ikan bandeng, kulit buah nanas, aquades steril, media $\mathrm{NA}, \mathrm{NaCl}$ $0,9 \%$, alkohol $96 \%, \mathrm{NaCH}_{3} \mathrm{COOH}$.

\section{Jenis Penelitian}

Penelitian ini merupakan penelitian eksperimen yaitu suatu metode penelitian yang digunakan untuk mencari pengaruh 
treatment (perlakuan) tertentu (Sugiyono, 2012).

\section{Rancangan Penelitian}

Penelitian menggunakan metode eksperimen dengan Rancangan Acak Lengkap (RAL) 3 ulangan dengan pola faktorial yang terdiri dari 2 faktor, yaitu :

Faktor I, Ikan disimpan di dalam kulkas dengan lama penyimpanan yang terdiri dari 3 tahap, yaitu $\mathrm{T}_{0}=2$ hari ; $\mathrm{T}_{1}=$ 4 hari ; $\mathrm{T}_{2}=6$ hari (Rakhmanda, 2008).

Faktor II, Konsentrasi sari kulit nanas yang terdiri dari $\mathrm{P}_{0}=0 \% ; \mathrm{P}_{1}=12,5 \% ; \mathrm{P}_{2}$ $=25 \% ; \mathrm{P}_{3}=50 \% ; \mathrm{P}_{4}=100 \%, 15$ kombinasi perlakuan dengan 3 ulangan.

\section{Prosedur Kerja}

Penelitian dilakukan melalui beberapa tahapan menurut Primahapsa, yaitu:

\section{Tahap Persiapan}

a. Sterilisasi Alat

Alat dan bahan yang akan dipakai disiapkan terlebih dahulu kemudian disterilisasi. Alat-alat tersebut dicuci dan dikeringkan. Tabung reaksi, gelas ukur, Erlenmeyer, cawan petri, pipet, dilindungi dengan cara dibungkusdengan kertas jagung, setelah itu diautoclave selama 1-2 jam pada suhu $121^{\circ} \mathrm{C}$. Untuk alat seperti mortal dan pistile disterilkan didalamoven pada suhu $121^{\circ} \mathrm{C}$ selama 15 menit.

b. Tahap pembuatan media NA

Bubuk NA ditimbang sebanyak 14 gram kemudian dilarutkan dalam 700 ml aquades steril pada gelas beker, selanjutnya dipanaskan di atas Hot Plate dan diaduk secara perlahanlahan. Saat NA mendidih, diangkat dan dituang ke dalam Erlenmeyer dan ditutup dengan kertas jagung, lalu disterilkan di autoclave dengan suhu $121^{\circ} \mathrm{C}$ selama $1-2$ jam. Selanjutnya media siap digunakan (Fathir, 2009).

c. Tahap pembuatan sari kulit nanas

Sari kulit nanas yang dipilih dengan kriteria kulit nanas yang telah tua yaituberwarna merah kehijauan sampai kuning kehijauan dan telah memunculkan aroma harum (Kumaunang, 2011). Cara membuat sari kulit nanas yaitu :

1) Sari kulit nanas diperoleh dengan cara menimbang $2 \mathrm{~kg}$ kulit nanas.

2) Kulit nanas dipotong kecil-kecil dan dicuci dengan air mengalir sampai bersih, diblender sampai hancur, disaring menggunakan kertas saring sehingga diperoleh sari kulit nanas.

3) Menambahkan $200 \mathrm{ml}$ baffer $\mathrm{NaCH}_{3} \mathrm{COOH}$ kemudian homogenkan dan tunggu sampai larutan mengendap dan ambil endapannya. Pembuatan sari kulit nanas dilakukan dengan konsentrasi yang berbeda-beda yaitu: $0 \%, 12,5 \%, 25 \%, 50 \%$ dan $100 \% \quad$ (Rosmawati, 2014). Pengenceran sari kulit nanas untuk 100 ml dari: $100 \%$ murni sari kulit nanas, dengan $50 \mathrm{ml}$ sari kulit nanas, $50 \mathrm{ml}$ aquadest steril

d. Tahap pembersihan dan persiapan sampel

Langkah pengolahan sampel melalui beberapa tahapan yaitu ikan bandeng dibersihkan bagian perutnya terlebih dahulu, kemudian dicuci dengan air sampai bersih. Ikan bandeng yang telah bersih kemudian diambil bagian dadanya dan dimasukkan kedalam toples yang telah diisi sari nanas dengan konsentrasi $0 \%, 12,5 \%, 25 \%$, $50 \%$ dan $100 \%$. Kemudian disimpan dalam lemari pendingin (kulkas) selama 2 hari, 4 hari dan 6 hari. Menurut Rosmawati (2014), Perlakuan yang dilakukan adalah :

P0 : Kontrol, yakni ikan disimpan tanpa diberi sari kulit nanas

P1 : Ikan + sari kulit nanas $12,5 \%$, disimpan selama 2 hari, 4 hari, 6 hari P2 : Ikan + sari kulit nanas $25 \%$, disimpan selama 2 hari, 4 hari, 6 hari P3 : Ikan + sari kulit nanas $50 \%$, disimpan selama 2 hari, 4 hari, 6 hari 
P4 : Ikan + sari kulit nanas $100 \%$, disimpan selama 2 hari, 4 hari, 6 hari Setelah penyimpanan, dilakukan pengenceran bertingkat sebanyak 10 gr/90 $\mathrm{ml} \mathrm{NaCL}$ dan aquades. Pengenceran dilakukan pada tingkat $10^{-}$ ${ }^{1}$ sampai $10^{-3}$.

\section{Tahap Inokulasi}

Cara kerja yang dilakukan dalam perhitungan bakteri adalah menumbuhkan bakteri pada media Nutrien Agar pada cawan petri dengan menggunakan metode tuang atau pour plate. Masing-masing pengenceran diambil suspensi sebanyak 1 $\mathrm{ml}$ dengan menggunakan pipet, lalu dipindahkan ke dalam cawan petri kemudian dituangkan Nutrien Agar cair sebanyak $10-15 \mathrm{ml}$ dengan suhu $\pm 40^{\circ} \mathrm{C}$. Cawan petri digerakkan perlahan-lahan agar suspensi tercampur rata dalam media, kemudian didiamkan selama 10-15 menit sampai Nutrien Agar menjadi dingin dan padat.

\section{Tahap Inkubasi}

Sampel pada cawan petri dengan ditambahkan media NA lalu diinkubator suhu $37^{\circ} \mathrm{C}$ selama 18 jam. Setelah akhir masa inkubasi koloni yang terbentuk dihitung. Perhitungan jumlah koloni dilakukan menggunakan alat hitung Coloni Counter. Cawan yang dipilih untuk perhitungan ialah yang mengandung antara 30 sampai 300 koloni bakteri. Untuk memperoleh data tentang jumlah koloni bakteri pada ikan bandeng yaitu dengan cara mengambil sampel ikan bandeng yang telah di beri perlakuan dan mengujinya di LaboratoriumBiologi UIN Raden Fatah Palembang.

\section{Uji Angka Lempeng Total (ALT)}

Metode kuantitatif digunakan untuk mengetahui jumlah mikroba yang adap ada suatu sampel, umumnya dikenal dengan Angka Lempeng Total (ALT). Dengan menggunakan media padat dengan hasil akhir berupa koloni yang dapat diamati secaravisual berupa angka dalam koloni (cfu) per $\mathrm{ml}$ atau per gram atau koloni/100ml. Carayang digunakan antara lain dengan cara tuang, cara tetes dan cara sebar (BPOM, 2007).

\section{Analisis Varian (ANOVA)}

Data yang diperoleh dianalisis menggunakan ANOVA (uji F) untuk menguji adanya pengaruh ekstrak kulit nanas (Ananas comosus (L) Merr) terhadap jumlah koloni bakteri pada ikan bandeng (Chanos chanos) (Hanafiah, 2012).

\section{Uji Lanjutan Beda Jarak Nyata Duncan (BJND)}

Jika $\mathrm{H}_{0}$ ditolak, untuk membedakan pengaruh dari masing-masing perlakuan dan menentukan perlakuan yang mana yang menunjukkan perbedaan nyata maka selanjutnya dilakukan Uji Beda Jarak Nyata Duncan (BJND) dengan rumus sebagai berikut:

$\mathrm{BNJD} \alpha=\mathrm{P} \alpha(\mathrm{p}, \mathrm{v}) \mathrm{X}$ s $\bar{y}$ (Hanafiah, 2012)

\section{HASIL DAN PEMBAHASAN}

Penelitian menggunakan metode eksperimen dengan Rancangan Acak Lengkap (RAL) 3 ulangan dengan pola faktorialyang terdiri dari 2 faktor. Hasil penelitian ini dapat dilihat pada gambar grafik (Gambar 1, Gambar 2, Gambar 3).

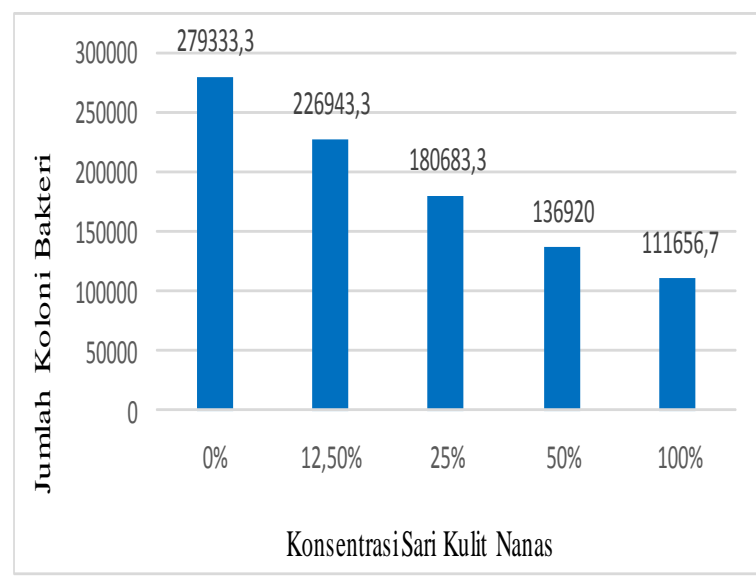

Gambar 1. Grafik jumlah koloni bakteri pada ikan bandeng (Chanos chanos Forsk.) 


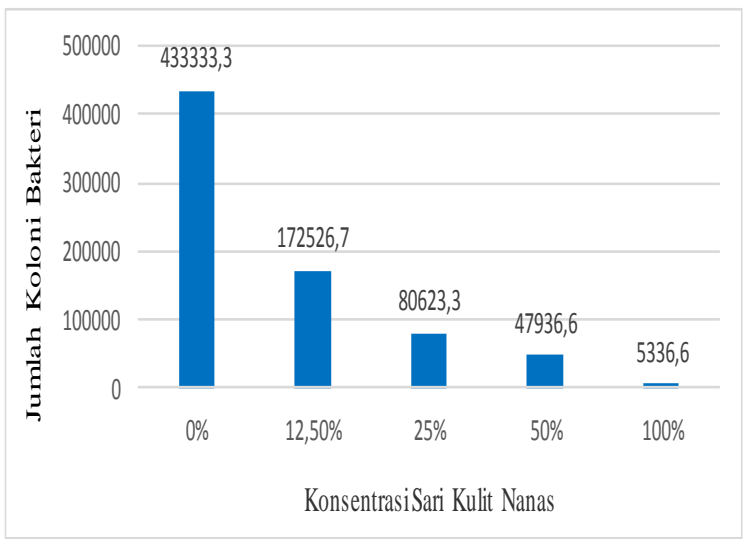

Gambar 2. Grafik jumlah koloni bakteri pada ikan bandeng (Chanos chanos Forsk.)

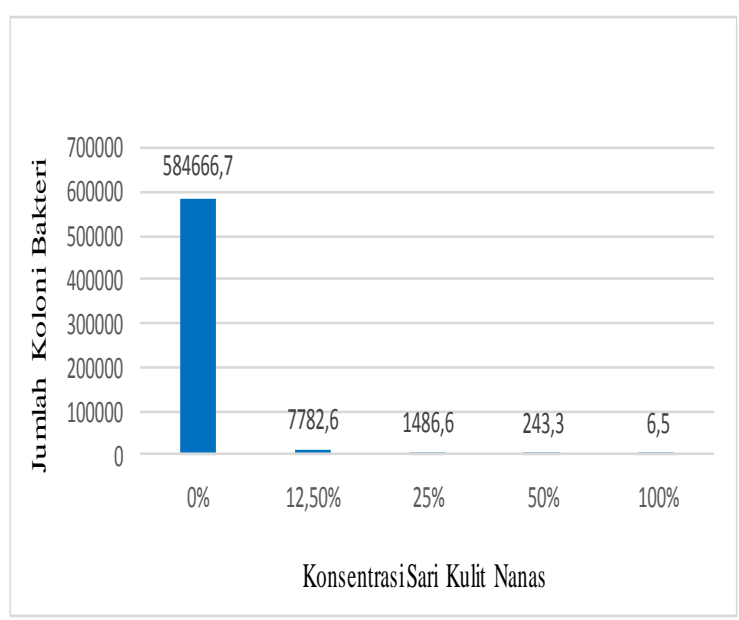

Gambar 3. Grafik jumlah koloni bakteri pada ikan bandeng (Chanos chanos Forsk.)

Berdasarkan hasil analisis sidik ragam, konsentrasi dan lama penyimpanan memberikan pengaruh yang sangat nyata terhadap jumlah koloni bakteri pada ikan bandeng (Chanos chanos F.), dimana nilai $F_{\text {hitung }}>F_{\text {tabel }}$ pada perlakuan yaitu 196,88 > 3,60 , pada faktor A yaitu $38,67>3,91$, sedangkan pada faktor B yaitu 513,91 > 4,18 dan pada interaksinya yaitu 77,93 > 4,43 dinyatakan bahwa $\mathrm{H}_{1}$ diterima dan $\mathrm{H}_{0}$ ditolak karena $F_{\text {hitung }}$ berbada sangat nyata dari $F_{\text {tabel. }}$ Sehingga selanjutnya untuk mengetahui perbedaan pengaruh dari masing-masing perlakuan dilanjutkan uji lanjut dengan menggunajan Uji Beda Nyata Duncan taraf $5 \%$ dan $1 \%$.

\section{Pengaruh pemberian sari kulit nanas pada jumlah koloni bakteri}

Berdasarkan hasil penelitian, diketahui bahwa sari kulit nanas (Ananas comosus (L.) Merr.) memiliki aktivitas sebagai aktimikroba pada ikan bandeng (Chanos chanos F.). Hal ini dapat dilihat dari jumlah koloni bakteri pada ikan bandeng yang direndam sari kulit nanas dan yang tidak direndam sari kulit nanas. Ikan yang tidak direndam sari kulit nanas memiliki jumlah koloni bakteri lebih banyak. Sedangkan ikan yang direndam sari kulit nanas memiliki jumlah bakteri lebih sedikit. Selain itu, pemberian sari kulit nanas juga berpengaruh pada jumlah koloni bakteri. Semakin tinggi konsentrasi sari kulit (Ananas comosus (L.) Merr.), maka pertumbuhan bakteri akan semakin dihambat pertumbuhannya sehingga terjadi perbedaan hasil jumlah koloni bakteri pada ikan bandeng. Hal tersebut sejalan dengan pernyataan Pelczar dan Chan (1988) yang menyatakan bahwa konsentrasi bahan antimikroba, dengan semakin tinggi konsentrasi bahan antimikroba maka semakin tinggi daya penghambatan terhadap aktivitas mikroba.

$$
\text { Menurut Indrawati (1992), }
$$

menyatakan bahwa aktivitas enzim bromelin dapat pula dipengaruhi oleh beberapa hal, diantaranya adalah kematangan buah, $\mathrm{pH}$, suhu, konsentrasi serta waktu. Buah nanas yang semakin matang maka aktivitasnya akan semakin berkurang. Hal ini disebabkan karena pada waktu proses pematangan buah, terjadi pembentukan senyawa enzim lain yang mungkin ikut terpakai dalam senyawa tersebut sehingga sebagian struktur enzim tersebut mengalami kerusakan dan akibatnya aktivitasnya akan berkurang.

Menurut Whitaker (1991), tanaman nanas mengandung enzim bromelin, yaitu suatu enzim proteolitik yang dapat mengkatalisis reaksi hidrolisis suatu ikatan peptida dari protein. Bagian buah yang lain seperti batang, kulit dan tangkai nanas juga mengandung enzim bromelin. Menurut 
Yandri dalam Kambey (2006), melaporkan bahwa kandungan enzim bromelin pada tanaman nanas antara lain terdapat pada buah nanas dengan aktivitas spesifik tertinggi yaitu $62,5 \mathrm{U} / \mathrm{mg}$; sedangkan pada batang nanas $27,3 \mathrm{U} / \mathrm{mg}$ dan pada kulit nanas $32,2 \mathrm{U} / \mathrm{mg}$.

\section{Konsentrasi optimum sari kulit nanas terhadap jumlah koloni bakteri}

Penelitian ini menggunakan medium NA untuk medium tumbuh bakteri. Penelitian ini menggunakan lima konsentrasi sari kulit nanas yaitu $0 \%$, $12,5 \%, 25 \%$, 50\%, dan 100\%. Pada konsentrasi $0 \%$ (tidak direndam sari kulit nanas) dan penyimpanan selama 2 hari menghasilkan jumlah bakteri $8,3 \times 10^{6}$, pada penyimpanan 4 hari menghasilkan jumlah koloni bakteri $1,3 \times 10^{7}$ dan pada penyimpanan 6 hari menghasilkan jumlah koloni bakteri $1,7 \times 10^{7}$. Pada konsentrasi $25 \%$ (25 $\mathrm{ml}$ sari kulit nanas) dengan penyimpanan 2 hari menghasilkan jumlah koloni bakteri $5,4 \times 10^{6}$, penyimpanan 4 hari menghasilkan jumlah koloni bakteri $1,4 \times 10^{6}$ dan penyimpanan 6 hari menghasilkan jumlah koloni bakteri sebanyak $4,4 \times 10^{4}$. Sedangkan pada konsentrasi $100 \%$ (murni sari kulit nanas) dengan penyimpanan selama 2 hari jumlah koloni bakeri $3,3 \times 10^{6}$, penyimpanan 4 hari menghasilkan jumlah koloni bakteri $1,6 \times 10^{5}$ dan penyimpanan 6 hari jumlah koloni bakteri sebanyak $6,5 \times 10^{2}$. Jumlah koloni bakteri yang dihasilkan berbedabeda, karena pemberian konsentrasi yang berbeda pada setiap perlakuan. Sehingga kandungan antimikroba yang terdapat pada sari kulit nanas juga berbeda. Hal ini menunjukkan bahwa konsentrasi $100 \%$ sari kulit nanas merupakan konsentrasi optimum untuk menghambat pertumbuhan bakteri pada ikan.

Konsentrasi sari kulit nanas yang berbeda menunjukkan perbedaan angka jumlah koloni bakteri, semakin tinggi konsentrasi sari kulit nanas semakin rendah pula jumlah koloni bakteri pada ikan bandeng. Namun dengan konsentrasi tinggi, sari kulit nanas jumlah koloni bakteri pada lama penyimpanan hingga 6 hari masih berada di bawah standar SNI $\left(5,0 \times 10^{5}\right)$. Perlakuan yang menunjukkan jumlah koloni bakteri berada di atas SNI $\left(5,0 \times 10^{5}\right)$ sebaiknya tidak untuk dikonsumsi karena tercemar dengan jumlah bakteri yang melebihi ambang batas.

\section{SIMPULAN}

Pemberian sari kulit nanas (Ananas comosus (L.)Merr.) memberikan pengaruh terhadap jumlah koloni bakteri. Berdasarkan uji ANOVA pada taraf 1\%, dimana $F_{\text {hitung }}>F_{\text {tabel }}$. Konsentrasi $100 \%$ berpengaruh nyata terhadap penurunan jumlah koloni bakteri pada ikan bandeng (Chanos chanos F.).

\section{DAFTAR PUSTAKA}

BPOM. (2007). Pengujian Mikrobiologi Pangan.

http://perpustakaan.pom.go.id/

KoleksiLainnya/InfoPOM/0207.pd f.

Buckle, K. A., Edward, R. A., Fleet, H.G., Wootton, M. (1987).Ilmu Pangan. Jakarta: Universitas Indonesia Press.

Caesarita, D.P. (2011). Pengaruh Ekstrak Buah Nanas (ananas comosus)100\% terhadap Bakteri Staphylococcus aureus dari Pioderma. Tugas Artikel Ilmiah. Semarang: UNDIP.

Fajar. (2013) .Waspada, Kebanyakan Ikan Kandung Formalin. (Online). (http://www.fajar.co.id/metromaka ssar/ Diakses 26 Juni 2014).

Fathir, F. (2009) . Media Pertumbuhan Mikroba.

http://fuadfathir.multiply.com/ journal/item/2/Media_Pertumbuha n_Mikroba. Diakses tanggal 10 agustus 2015.

Hanafiah, K., (2012). Rancangan Percobaan Teori dan Aplikasi. Raja Grafindo Persada,Jakarta. 
Indrawati, T. (1992). Pembuatan Kecap Keong Sawah Dengan Menggunakan Enzim Bromelin. Semarang. Balai pustaka dan media Wiyata.

Kambey, N. (2006). Pengolahan Minyak Kelapa dengan Penambahan Enzim Bromelin dari kulit Nanas(Ananascomosus L). Skripsi. FMIPA.

Kumaunang, M., Vanda, K. (2011). Aktivitas Enzim Bromelin Dari Ekstrak Kulit Nenas (Anenas comosus). FMIPA Universitas Sam Ratulangi : Manado.

MAI (Masyarakat Akuakultur Indonesia). (2014). Bandeng: Indonesia MasihJawara. (Online). (http://www.aquaculturemai.org/.Diakses 26 Juni 2014).

Mahatmanti, W. F., Warlan, S., Wisnu, S. (2010). Sintesis Kitosandan Pemanfaatan sebagai Anti Mikrobia Ikan Segar. Jurnal Sains dan Teknologi ISSN.02131366. Vol.8 no. 2 .

Pelczar, M. J. dan Chan, E. C. S. (1988). Dasar-dasar Mikrobiologi 1. Jakarta: UI Press.
Purnowati, I., Hidyati, D., dan Suparinto, C. (2007). Ragam Olahan Bandeng. Kanisius, Yogyakarta

Puspita, S. (2012). Pengawetan Suhu Rendah Pada Daging dan Ikan. Universitas Diponogoro, Semarang.

Purnomowati, I., Hidayati, D., dan Saparinto, C. (2007). Ragam Olahan Bandeng. Yogyakarta: Kanisius.

Rakhmanda, A. P. (2008). Perbandingan Efek Antibakteri Jus Nanas (Ananascomosus L.merr) pada Berbagai Konsentrasi terhadap Streptococcus mutans. Tugas Artikel Ilmiah. Semarang : Universitas Diponegoro.

Rosmawati. (2014). Aktivitas Enzim Bromelin Dari Ekstrak Kulit Nenas (Anenas comosus).Universitas Sam Ratulangi. Manado.

Sugiyono. (2012). Metode Penelitian Pendidikan. Bandung: Alfabeta

Whitaker, J. R. (1991). Principles of Enzimology For The Food Sciences.Marcel Dekker Inc. New York. 